\title{
Prenatal, biological and environmental factors associated with physical activity maintenance from childhood to adolescence
}

\author{
Fatores pré-natais, biológicos e ambientais associados \\ à manutenção da atividade física da infância à adolescência
}

\begin{abstract}
André Oliveira Werneck ${ }^{1}$ Danilo Rodrigues Silva ${ }^{1}$ Paul James Collings ${ }^{2}$ Rômulo Araújo Fernandes ${ }^{3}$ Enio Ricardo Vaz Ronque ${ }^{1}$ Luís Bettencourt Sardinha ${ }^{4}$ Edilson Serpeloni Cyrino ${ }^{1}$
\end{abstract}

${ }^{1}$ Grupo de Estudo e Pesquisa em Metabolismo, Nutrição e Exercício, Universidade Estadual de Londrina. Rodovia Celso Garcia Cid - Pr $445 \mathrm{Km}$ 380, Campus Universitário. 86057-970 Londrina PR Brasil. andreowerneck@gmail.com ${ }^{2}$ Bradford Institute for Health Research, Bradford Teaching Hospitals Foundation Trust. Bradford UK

${ }^{3}$ Departamento de Educação Física, Faculdade de Ciências e Tecnologia de Presidente Prudente, Universidade Estadual Paulista. Presidente Prudente SP Brasil. ${ }^{4}$ Faculdade de Motricidade Humana, Universidade de Lisboa. Lisboa Portugal.
Abstract Our aim was to identify prenatal, biological and environmental correlates of child to adolescence physical activity maintenance in 1,186 Brazilian youth (525 boys) aged between 10 and 16 years. Current and former physical activity levels were obtained cross-sectionally through questionnaires. As potential correlates, parent's activity levels, socioeconomic status and offspring's birth weight were self-reported by parents. Somatic maturation was estimated by the peak of height velocity. Logistic regression analyses revealed that, regardless of chronological age, males were more likely to be active in childhood $(\mathrm{OR}=1.73$ [CI $95 \%=1.33$ to 2.27$]$ ) and to maintain physical activity (adjusted by chronological age, sex, birth weight and mother's physical activity) $(O R=3.58$ [CI 95\% = 2.32 to 5.54]), as well as late maturing adolescents ( $O R=2.52$ [CI 95\% $=1.02$ to 6.22]). Adolescents whose mother was inactive $(\mathrm{OR}=$ 0.31 [CI 95\% = 0.11 to 0.86]) also had a lower probability of maintaining physical activity. Thus, girls, adolescents born with low weight and those with inactive mother are less likely to maintain physical activity levels from childhood to adolescence.

Key words Motor activity, Health behavior, Puberty, Social learning
Resumo O nosso objetivo foi identificar correlatos pré-natais, biológicos e ambientais da manutenção da prática de atividade física da infância à adolescência em 1.186 adolescentes (525 meninos), com idade entre 10 e 16 anos. Prática de atividade física na infância (retrospectiva) e adolescência (atual) foi obtida através de questionários. O nível de atividade física dos pais, nível socioeconômico e peso ao nascer dos filhos foram relatados pelos pais. Maturação somática foi estimada por meio do pico de velocidade de crescimento. Regressões logísticas revelam que independentemente da idade cronológica, meninos apresentaram maior probabilidade de ser ativos na infância $(O R=$ 1.73 [CI 95\% = 1.33 - 2.27]) e manter a prática de atividade física (ajustado por idade cronológica, sexo, peso ao nascer e atividade física da mãe) $(O R=3.58$ [CI 95\% = $2.32-5.54])$, bem como adolescentes com maturação tardia $(O R=2.52$ [CI 95\% = $1.02-6.22]$ ), adolescentes com a mãe inativa $(O R=2.52$ [CI 95\% = $1.02-6.22])$, também apresentaram menor probabilidade de manter o nível de atividade física. Portanto, meninas, adolescentes nascidos com baixo peso e aqueles cuja mãe é inativa possuem menor probabilidade de manter o nível de atividade física da infância à adolescência.

Palavras-chave Atividade motora, Comportamentos saudáveis, Puberdade, Aprendizagem social 


\section{Introduction}

Although the benefits of physical activity are well established, a high prevalence of physical inactivity has been observed in different population groups ${ }^{1}$. It is estimated that inactivity is responsible for $9 \%$ of premature deaths worldwide, representing the greatest isolated cause of death ${ }^{1}$. Health promotion efforts based on ecological models, which act on different levels of correlates and determinants of physical activity in specific groups, have been recommended ${ }^{2}$. Among them, early-life factors such as prenatal development and birth weight, and their interaction with environmental factors have been studied to provide a better understanding of habitual physical activity patterns $s^{3-5}$.

Early experience of physical activity has been identified as an important correlate of physical activity throughout life $e^{6,7}$. An active lifestyle in childhood is associated with health in adulthood $^{8-10}$ through several direct pathways involving body fat and the methylation of some genes ${ }^{10}$ and/or indirectly by tracking effects ${ }^{7}$.

The influence of the social environment on physical activity has been also widely studied in youth. Especially during the first years of life, parental behaviors tend to be transferred to infants and children ${ }^{11,12}$. Maternal and paternal influences may manifest through support, encouragement or modeling, and their relationships tend to vary according to physical activity type. For example, a review found that parent's support (mainly paternal) predicted overall children's physical activity, but the results were contradictory for different domains of physical activity ${ }^{13}$. With regards to physical activity maintenance, social support seems to be important for adolescents, but the results for parental constructs are currently inconclusive ${ }^{14}$.

It is speculated that early life, even intrauterine factors, may be related to biological outcomes and some behaviors ${ }^{3}$. Poor and delayed fetal growth, frequently assessed through the birth weight, is associated with poor motor development, which could be related to lifestyle adoption, playing as a mediator in this relationship ${ }^{15}$. Similarly, the association between gestational timing and physical activity in different periods of life is not clear ${ }^{16}$. Moreover, birth weight has been associated with cardiovascular risk in adulthood, whereas both low and high values are negatives ${ }^{17,18}$. A recent meta-analysis concluded that in youth the relationship between birth weight and biological outcomes is not mediated by physical activity ${ }^{19}$. However, no data are available about the role of birth weight in physical activity maintenance from infancy to adolescence. Furthermore, whether prenatal and environment influences may interact to determine physical activity patterns is not clear. Previous studies on this topic have not controlled for biological variability ${ }^{5,13}$ and physical activity maintenance is rarely treated as an outcome ${ }^{14}$.

Increased understanding of the factors that are related to the practice and maintenance of physical activity throughout life can help to formulate strategies to tackle the current physical inactivity pandemic. Thus, our aim was to identify prenatal, biological and environmental factors associated with the maintenance of physical activity participation from childhood to adolescence in Brazilian adolescents. Our hypothesis was that prenatal, individual and parental variables, were correlates of physical activity participation from childhood to adolescence.

\section{Methods}

\section{Design and sampling}

This was a cross-sectional study conducted in the city of Londrina/PR with adolescents aged between 10 and 16 years old, who were enrolled in public schools. Londrina has 506,701 inhabitants, an HDI of 0.778 and a GDP per capita of US\$ $8,530.77^{20}$. The sampling process was performed in two stages. Initially, all the public schools of Londrina were separated into regions (north, south, east, west and center), two schools were then randomly selected from each region. After this, the classes were randomly selected from schools (three or four depending of the size). All students from each randomly selected class were invited to participate in the study. For which, the sample size calculation was estimated for a greater project named "Prevalence of metabolic syndrome and cardiovascular risk factors in adolescents from Londrina" that was based on a prevalence of metabolic syndrome of $4 \%$, a of 0.05 , a margin of error of two percentage points, and a design effect of 2.0. The total sample was composed by 1,395 adolescents. However, 209 were excluded from the sample for this study due to missing data of individual correlates. Concerning parental variables, the number of missing data was greater (Maternal: 519; Paternal: 649). Those adolescents who were using prescription medicine, undergoing treatment for any disease, 
The Baecke questionnaire ${ }^{22}$ was self-completed by adolescents and used as an indicator of current physical activity level (adolescence). This instrument contains questions related to physical activity at school, leisure time and sports, and the sum of which constitutes an estimative of habitual physical activity. For reproducibility estimative, the questionnaire was repeated on a representative portion of the sample (10\%) after an interval of seven days and the intra-class correlation coefficient (ICC) was 0.73 . Because the Baecke questionnaire was not designed to prevalence propose (allows to estimate the maximum of 240 minutes), adolescents in the highest quartile of the sample distribution were considered 'active'. Past experience with sports practice in mid-childhood was adopted as a former physical activity indicator. A dichotomous question (yes or no) of engagement in supervised sports participation for at least one year between the ages of seven and 10 years was answered by the adolescent $(\mathrm{ICC}=0.87)$. Finally, to evaluate parental physical activity, the Baecke questionnaire was again applied. Once this questionnaire do not allows only the categorization according physical activity guidelines, parents who reported spending at least 180 minutes per week in moderate to vigorous physical activity were considered 'active'.

\section{Gestational age and birth weight}

Both gestational age and birth weight was assessed by a questionnaire answered by parents. From this, we categorized adolescents as preterm if their parents reported birth occurring before 37 weeks. With regards birth weight, subjects were divided into three categories: low (lowest quartile, $\leq 2.870 \mathrm{~kg}$ ), normal (two central quartiles, 2.871 to 3.610 ) and high (highest quartile, $\geq 3.620$ ).

\section{Socioeconomic status}

Socioeconomic status was assessed through the Brazilian Criterion for Economic Classification instrument ${ }^{23}$ which classifies families into

one of five alphabetical groups ranging from A (high SES) to E (low SES), according to family possessions and the educational level of the head of household. For this study, groups A and B were combined to reflect 'highest SES' and groups C, D and $\mathrm{E}$ were combined to reflect 'lowest SES', because of the homogeneous socioeconomic status.

\section{Somatic maturation}

Somatic maturity was estimated using the peak of height velocity (PHV) ${ }^{24}$. The distance to PHV was calculated from information on height, trunk-cephalic height and leg length. Additionally, chronological age was subtracted from the distance to PHV for classification according to maturity categories in boys (late $>14.8$ years; on time: 14.8 to 13.4 years; early $<13.4$ years $)$ and girls (late $>13.0$ years; on time: 13.0 to 11.8 years; early $<11.8$ years). Also, body weight was measured for calculating body mass index (BMI).

\section{Statistical analyses}

The characteristics of the sample were described as frequencies, means and standard deviations. The Mann-Whitney and Kruskal-Wallis tests were used for group comparisons. Linear trends were tested by the Chi-Square test. To investigate correlates of physical activity maintenance from mid-childhood to adolescence, multinomial logistic regression adjusted for chronological age was used with separate models for sex, birth weight and parental physical activity as independent variables (model 1). Poisson regression with robust variance provide better estimates for cross-sectional studies, mainly when the outcome is highly prevalent. However, we have adopted an ordinal outcome with three categories (1 - no physical activity; 2 - physical activity only in childhood; and 3 - physical activity in both childhood and adolescence), avoiding this approach and multinomial logistic regression become more suitable in our case. Latterly, all significant variables from model 1 were included simultaneously in a model to mutually adjust for one another (model 2). Although our sampling randomization was conducted by clusters (school), the intra-cluster correlation coefficients were low, ranging between 0.006 and 0.009 (physical activity: 0.008; Sex: 0.008; Gestational age: 0.009; Birth weight: 0.008; Socioeconomic status: 0.006; Maternal physical activity: 0.008; Paternal physical activity: 0.008; somatic maturation: 0.009), which indicates a low variance 
between clusters. All analyses were performed in the SPSS 20.0 and the significance level adopted was $\mathrm{p}<0.05$.

\section{Results}

Of the 1,395 initial study participants, 209 did not possess complete data for the variables and were excluded. The results in the present work are therefore based on 1,186 adolescents for individual variables and 876/746 for maternal and paternal variables respectively, of which $44.4 \%$ were boys and $67.4 \%$ presented low socio economic status. The characteristics of the sample according to physical activity patterns (inactive in childhood and adolescence, active only in childhood and active in both periods) are presented in Table 1.

Differences between groups were observed regarding somatic maturity status $(p<0.001)$, in which adolescents classified as active in both childhood and adolescence presented with later (late) age at PHV. Figure 1 presents the prevalence of physical activity patterns according to sex, socioeconomic status, birth weight, biological maturity status and physical activity of parents.

There was a higher prevalence of maintenance of physical activity in boys $(p=0.002)$ and those whose mothers were considered physically active $(p=0.043)$. In adjusted associations (Table 2), we found that boys were $73 \%$ more likely to be active in childhood and almost four times more likely to be active in childhood and adolescence when compared with girls. Adolescents with late (later-onset) maturity had 2.5 times higher odds of being active in childhood and adolescence compared with early maturers. Similarly, adolescents whose mothers were classified

Table 1. Sample characteristics.

\begin{tabular}{lrrrr}
\hline & No PA & $\begin{array}{c}\text { PA in } \\
\text { childhood }\end{array}$ & $\begin{array}{c}\text { PA in } \\
\text { childhood and } \\
\text { adolescence }\end{array}$ & p \\
\hline Chronological & $12.9 \pm 1.5$ & $12.9 \pm 1.5$ & $13.1 \pm 1.7$ & 0.456 \\
Age (y) & & & & \\
Age of PHV (y)* & $13.0 \pm 1.2$ & $13.3 \pm 1.2$ & $13.7 \pm 1.2$ & $<0.01$ \\
BMI (ml/kg $\left.{ }^{2}\right)$ & $19.8 \pm 4.2$ & $20.0 \pm 4.0$ & $20.0 \pm 4.0$ & 0.508 \\
Birth weight $(\mathrm{cm})$ & $3.2 \pm 0.7$ & $3.2 \pm 0.6$ & $3.3 \pm 0.7$ & 0.506 \\
\hline $\begin{array}{l}\text { Note. PHV = Peak Height Velocity. BMI = body mass index. PA = physical } \\
\text { activity. SES = socioeconomic status. }{ }^{*} \text { Differences between all groups. }\end{array}$
\end{tabular}

as inactive had $69 \%$ lower odds of being active in both periods.

\section{Discussion}

This was a cross-sectional study using current and retrospective information about physical activity engagement by Brazilian adolescents. We aimed to investigate factors that were associated with the maintenance of physical activity during the early stages of life (childhood and adolescence). The main results indicated that boys were more likely to be active in both childhood and adolescence, while adolescents whose mothers were inactive and who are early maturing were less likely to be active in childhood and adolescence. These findings indicate some possibilities for effective physical activity promotion interventions during the first two decades of life, by identifying highrisk groups and highlighting important social correlates of physical activity maintenance.

Physical activity performed in the early years of life seems to be an important strategy for its maintenance in later stages. Though there is consistent evidence of a decrease in physical activity from childhood to adolescence ${ }^{6,25}$, during adolescence ${ }^{7,26}$ and beyond, caused by several factors, passing from biological ones to behavioral factors as a different social context with more responsibilities and different interests ${ }^{27}$. Continuity of physical activity over the lifespan is important because, either directly or indirectly, activity has positive effects on several physical and mental health outcomes. Physical activity may help to protect from excess body fat development ${ }^{28}$ which has a strong relationship with cardiovascular risk ${ }^{29}$. Moreover, physical activity is related to cardiorespiratory fitness $s^{30}$, which constitutes an important protective factor for cardiovascular risk and can even attenuate the negative health effects of overweight and obesity ${ }^{31}$.

One of the pathways recently highlighted for the benefits of physical activity in childhood and throughout life is the genetic methylation of DNA. Epigenetic pathways of modification of genes related to cardiovascular outcomes have been highlighted ${ }^{10,32,33}$ in an attempt to explain the effects of physical activity in childhood, independent of habits in adulthood ${ }^{8,9}$.

Knowledge of the factors that determine PA maintenance and not merely its engagement in childhood is important, particularly as PA levels decline with advancing age. In the present study it was observed that in addition to being more 

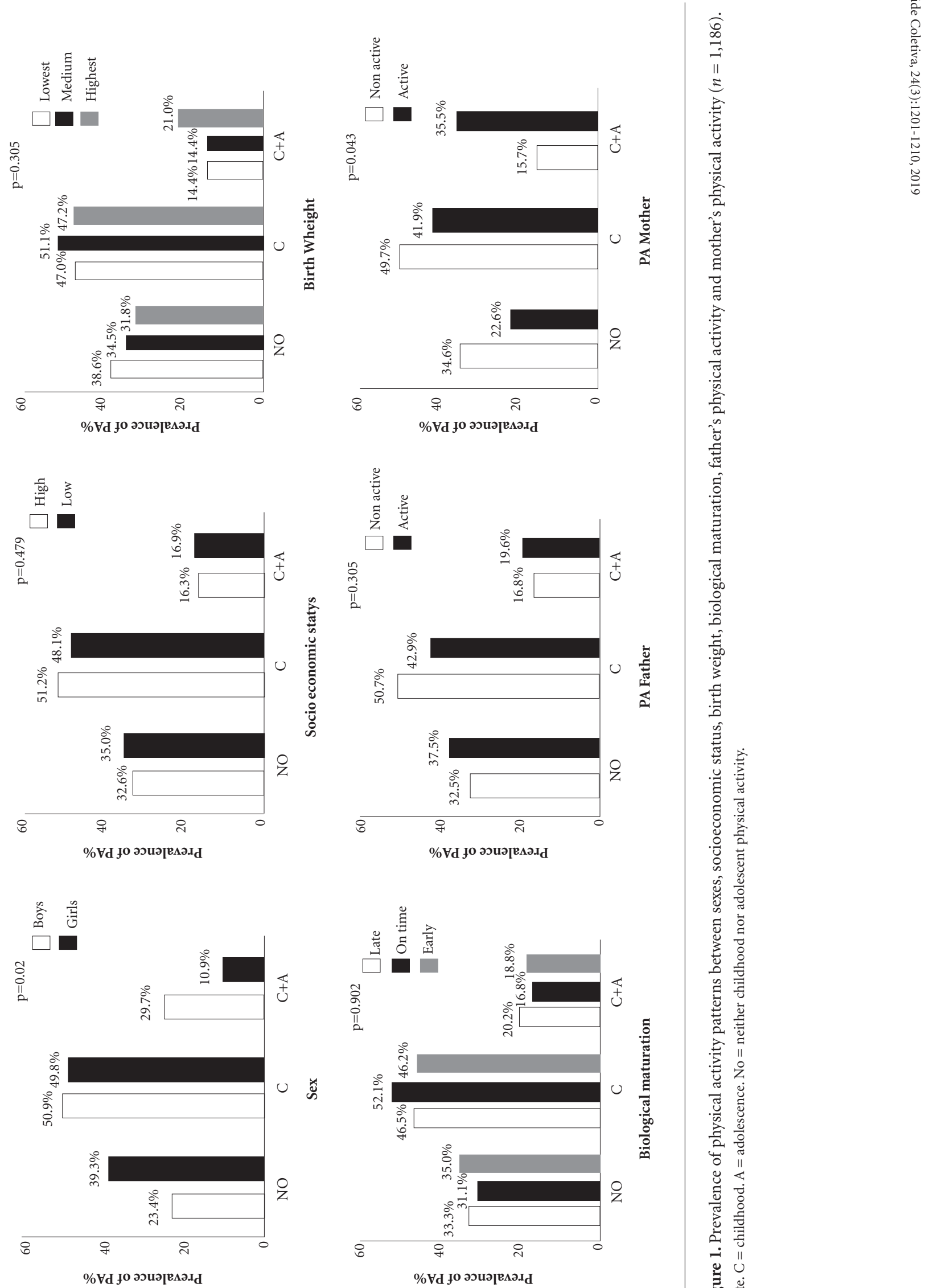

है


Table 2. Association between physical activity pattern and correlates in Brazilian adolescents $(n=1,186)$.

\begin{tabular}{|c|c|c|c|c|}
\hline \multirow[t]{2}{*}{ Correlates } & \multirow[t]{2}{*}{ No PA } & \multirow{2}{*}{$\begin{array}{c}\text { PA in childhood } \\
\text { Model } 1\end{array}$} & \multicolumn{2}{|c|}{ PA in childhood and adolescence } \\
\hline & & & Model 1 & Model 2 \\
\hline \multicolumn{5}{|l|}{ Sex } \\
\hline Female & Ref. & 1 & 1 & 1 \\
\hline Male & Ref. & $1.73(1.33$ to 2.27$)$ & $3.94(2.75$ to 5.64$)$ & $3.58(2.32$ to 5.54$)$ \\
\hline \multicolumn{5}{|l|}{ Gestational age } \\
\hline Preterm & Ref & 1 & 1 & 1 \\
\hline Term & Ref & $1.10(0.79$ to 1.51$)$ & $1.03(0.67$ to 1.60$)$ & $1.04(0.66$ to 1.63$)$ \\
\hline \multicolumn{5}{|l|}{ Birth weight } \\
\hline Highest & Ref. & 1 & 1 & 1 \\
\hline Middle & Ref. & $0.99(0.68$ to 1.44$)$ & $0.64(0.39$ to 1.03$)$ & $0.77(0.47$ to 1.29$)$ \\
\hline Lowest & Ref. & $0.82(0.54$ to 1.25$)$ & $0.57(0.32$ to 0.99$)$ & $0.69(0.38$ to 1.24$)$ \\
\hline \multicolumn{5}{|l|}{ Socioeconomic status } \\
\hline Highest & Ref. & 1 & 1 & 1 \\
\hline Lowest & Ref. & $0.87(0.64$ to 1.18$)$ & $0.97(0.64$ to 1.47$)$ & $1.23(0.91$ to 1.66$)$ \\
\hline \multicolumn{5}{|l|}{ Mother's PA } \\
\hline Active & Ref. & 1 & 1 & 1 \\
\hline Inactive & Ref. & $0.77(0.30$ to 1.96$)$ & $0.29(0.11$ to 0.78$)$ & $0.31(0.11$ to 0.86$)$ \\
\hline \multicolumn{5}{|l|}{ Father's PA } \\
\hline Active & Ref. & 1 & 1 & \\
\hline Inactive & Ref. & $1.40(0.76$ to 2.58$)$ & 0.95 (0.44 to 2.05$)$ & $0.92(0.38$ to 2.23$)$ \\
\hline \multicolumn{5}{|l|}{ Somatic maturity } \\
\hline Early & Ref. & 1 & 1 & 1 \\
\hline On time & Ref. & 0.95 (0.58 to 1.57$)$ & $1.31(0.89$ to 1.93$)$ & 1.85 (0.90 to 3.64$)$ \\
\hline Late & Ref. & $0.94(0.47$ to 1.90$)$ & $1.15(0.67$ to 2.00$)$ & $2.52(1.02$ to 6.22$)$ \\
\hline
\end{tabular}

Note. Values are expressed in odds ratio (95\% confidence interval). Multinomial logistic regression was adopted (no PA as reference group). Model 1: adjusted by chronological age. Model 2: Model $1+$ sex, birth weight and mother's PA. No = neither childhood nor adolescence physical activity. SES = socioeconomic status. PA = physical activity.

active in childhood, boys were more likely to remain physically active in adolescence compared to girls. This maybe partially explained by boys being more socially stimulated to perform sports, especially during outside school hours. In addition, other social factors such as freedom and parental support for physical activity (for example, transporting to the training place and providing encouragement for sports participation) may be afforded more to boys than girls ${ }^{34}$.

Also, the influence of parents can be indirect, through social learning of some behaviors; given that the environment in which the young person lives and parental examples may influence their habits ${ }^{13,35}$. Accordingly, we observed that children of inactive mothers were less likely to be active from childhood through adolescence. In other words, it seems that maternal behaviors may promote adherence of young people to physically activity lifestyles. The absence of father's PA influence on youth PA patterns maybe relat- ed to the role of mothers as primary caregivers through early childhood. Regardless, our data highlight the importance of parent's (particularly maternal) physical activity to aid maintenance of healthy habits through childhood. In addition to the modeling, probably active parents tend to support and encourage more their children to be active. Thus, we suppose that strategies to promote physical activity in young people should therefore include parental-levels actions.

Following adjustment for sex, birth weight and mother's PA, we observed that late maturing adolescents were more likely to be active in both childhood and adolescence. Sherar et al. ${ }^{36}$ highlight the complex relationships between biological and behavioral variables during the pubertal transition. Morphological alternations are typically followed by cognitive changes which may have an impact on PA more than just chronological age ${ }^{37}$. This highlights the importance of controlling for biologic maturation in physical 
activity studies involving adolescents, and as the timing of puberty differs between boys and girls adjustment for sex is also needed.

Another important finding of this study was the relationship between birth weight and maintenance of physical activity from childhood to adolescence (model 1). We observed that adolescents who were born with a low birth weight (lowest quartile) presented a lower prevalence of physical activity in both stages (childhood and adolescence) when compared to the highest quartile. Gopinath et al. $^{5}$, in a five year follow up study, observed that in adolescents between 12 and 13 years old and 17 and 18 years old, birth weight was directly related to habitual physical activity, even after adjustment for important variables such as ethnicity, parental education, body mass index and gestational period. Despite the mechanisms inherent in the association of birth weight with the adoption and maintenance of certain behaviors being unclear, it is speculated that the influence of low birth weight on the components of physical fitness (muscular mass, motor coordination and cardiorespiratory fitness) ${ }^{15,38,39}$, which are related to success and adherence in sports participation, could explain this relationship. However, when the analyses were adjusted by sex and mother's PA, birth weight was no longer associated with PA maintenance. A recent systematic review found that none of the studies with objectively measured physical activity have observed an association between birth weight and physical activity; a result that was confirmed by meta-analyses of all identified studies ${ }^{19}$.

We highlight that although studies have found that prenatal exposures can influence future health and well-being (the development origins of health and disease hypothesis $)^{3,40}$, these associations are unlikely mediated by prenatal factors determining habitual physical activity. Our data indicate that the social environment is more strongly associated with youth PA levels than early life events. Regardless of gestational period and birth weight, adolescents with active mothers were more likely to maintain PA levels from childhood to adolescence.

In this sense, practical implications can be inferred from our findings. Having in mind that the main correlates of physical activity maintenance from childhood to adolescence were sex, maternal physical activity and biological maturation, these adolescents with risk of be inactive should receive especial attention and be target of public health policies. Moreover, ecological interventions that also involves the family of the subject, promoting family-based interventions to promote physical activity seems to be promising ${ }^{41}$.

Limitations of this study include the design (which do not allow causality establishing) and the subjective methods to assess physical activity, gestational age and birth weight. Birth outcomes, however, are known to be reported with certain accuracy by parents ${ }^{42}$, especially through categorical questions as we categorized in the present study. Araújo et al. ${ }^{43}$ found a bias of $0.20 \mathrm{~kg}$ between measured and recalled birth weight as well as an agreement of approximately $95 \%$ when birth weight was reported categorically. However it can contain bias according educational status $^{42,43}$. Self-reported physical activity, and in particular the retrospective reporting of sports participation in mid-childhood, represents just one domain of physical activity. Self-report techniques are known to have lower validity than objective methods, but their use for physical activity assessment in low and middle-income countries is still limited ${ }^{7,44}$. Thus, studies have adopted similar strategies in an attempt to identify the effects of early physical activity practice on outcomes later in life $\mathrm{e}^{8,10,45}$

Moreover, due to our sample size and consequently unequal distribution of adolescents between physical activity patterns, we could not analyze adolescents that were inactive during childhood, but are currently active, because of the small number of adolescents in this condition. Similarly, the number of mothers that participated in this study was larger than fathers (876 vs 746), which can cause bias and a possible lack of association between paternal physical activity and offspring physical activity. Consequently, we had a big quantity of missing data, what can also cause bias, even that there were no differences of the characteristics between missing data and included data. On the other hand, we considered prenatal, biological and environmental correlates of child to adolescence physical activity maintenance of a understudied population on a view of sports/physical activity maintenance from childhood to adolescence.

Finally, we conclude that girls, children of inactive mothers and early maturing adolescents are less likely to maintain physical activity participation from childhood to adolescence. We emphasize the need of specific strategies for the promotion of physical activity adoption and maintenance toward these groups. 


\section{Collaborations}

DRP Silva: acquisition, analysis/interpretation of data. AO Werneck and PJ Collings: Analysis and interpretation of data. RA Fernandes, ERV Ronque, LFCB Sardinha and ES Cyrino: interpretation of data and important review of the final version to be submitted.

\section{Acknowledgements}

The authors thank Alessandra Okino, Jair Oliveira, Danielle Venturini and Décio Barbosa for research support. Crisieli Tomeleri, Mariana Carnelossi and Sandra Kawaguti for acquisition of data. Coordination for the Improvement of Higher Education Personnel (CAPES/BRAZIL) for scholarships (DRPS), FAPESP for scholarship of AO Werneck (process 2017/27234-2) and National Council of Scientific and Technological Development (CNPq/BRAZIL) for funding the project and for scholarship productive research (ERV Ronque, ES Cyrino and RA Fernandes).

\section{References}

1. Lee IM, Shiroma EJ, Lobelo F, Puska P, Blair SN, Katzmarzyk PT; Lancet Physical Activity Series Working Group. Effect of physical inactivity on major non-communicable diseases worldwide: an analysis of burden of disease and life expectancy. Lancet 2012; 380(9838):219-229.

2. Bauman AE, Reis RS, Sallis JF, Wells JC, Loos RJ, Martin BW; Lancet Physical Activity Series Working Group. Correlates of physical activity: why are some people physically active and others not? Lancet 2012; 380(9838):258-271.

3. Adamo KB, Langlois KA, Brett KE, Colley RC. Young children and parental physical activity levels: findings from the Canadian health measures survey. Am J Prev Med 2012; 43(2):168-175.

4. Archer E, Lavie CJ, McDonald SM, Thomas DM, Hébert JR, Taverno Ross SE, McIver KL, Malina RM, Blair SN. Maternal inactivity: 45-year trends in mothers' use of time. Mayo Clin Proc 2013; 88(12):13681377.

5. Gopinath B, Hardy LL, Baur LA, Burlutsky G, Mitchell P. Birth Weight and Time Spent in Outdoor Physical Activity during Adolescence. Med Sci Sports Exerc 2013; 45(3):475-480.

6. Jones RA, Hinkley T, Okely AD, Salmon J. Tracking Physical Activity and Sedentary Behavior in Childhood A Systematic Review. Am J Prev Med 2013; 44(6):651658.

7. Azevedo MR, Menezes AM, Assuncao MC, Gonçalves H, Arumi I, Horta BL, Hallal PC. Tracking of physical activity during adolescence: the 1993 Pelotas Birth Cohort, Brazil. Rev Saude Publica 2014; 48(6):925-930.

8. Fernandes RA, Zanesco A. Early physical activity promotes lower prevalence of chronic diseases in adulthood. Hypertens Res 2010; 33(9):926-931.

9. Lima MC, Barbosa MF, Diniz TA, Codogno JS, Freitas Junior IF, Fernandes RA. Early and current physical activity: relationship with intima-media thickness and metabolic variables in adulthood. Braz J Phys Ther 2014; 18(5):462-469.

10. Fernandes RA, Coelho-E-Silva MJ, Spiguel Lima MC, Cayres SU, Codogno JS, Lira FS. Possible underestimation by sports medicine of the effects of early physical exercise practice on the prevention of diseases in adulthood. Curr Diabetes Rev 2015; 11(3):201-205

11. Franks PW, Ravussin E, Hanson RL, Harper IT, Allison DB, Knowler WC, Tataranni PA, Salbe AD. Habitual physical activity in children: the role of genes and the environment. Am J Clin Nutr 2005; 82(4):901-908.

12. Notten N, Kraaykamp G, Konig RP. Family media matters: unraveling the intergenerational transmission of reading and television tastes. Sociol Perspect Win 2012; 55(4):683-706.

13. Edwardson CL, Gorely T. Parental influences on different types and intensities of physical activity in youth: A systematic review. Psychol Sport Exerc 2010; 11(6):522535.

14. Craggs C, Corder K, van Sluijs EM, Griffin SJ. Determinants of change in physical activity in children and adolescents: a systematic review. Am J Prev Med 2011; 40(6):645-658. 
15. Rogers M, Fay TB, Whitfield MF, Tomlinson J, Grunau RE. Aerobic capacity, strength, flexibility, and activity level in unimpaired extremely low birth weight (\&lt; = $800 \mathrm{~g}$ ) survivors at 17 years of age compared with termborn control subjects. Pediatrics 2005; 116(1):E58-E65.

16. Kaseva N, Martikainen S, Tammelin T, Hovi P, Järvenpää AL, Andersson S, Eriksson JG, Räikkönen K, Pesonen AK, Wehkalampi K, Kajantie E. Objectively measured physical activity in young adults born preterm at very low birth weight. J Pediatr 2015; 166(2):474-476.

17. Oken E, Gillman MW. Fetal origins of obesity. Obes Res 2003; 11(4):496-506.

18. Lawlor DA, Harro M, Wedderkopp N, Andersen LB, Sardinha LB, Riddoch CJ, Page AS, Anderssen SA, Froberg K, Stansbie D, Davey Smith G. Association of socioeconomic position with insulin resistance among children from Denmark, Estonia, and Portugal: cross sectional study. BMJ 2005; 331(7510):183.

19. Øglund GP, Hildebrand M, Ekelund U. Are Birth Weight, Early Growth and Motor Development Determinants of Physical Activity in Children and Youth? A Systematic Review and Meta-Analysis. Pediatr Exerc Sci 2015; 27(4):441-453.

20. Statistics BIoGa. Gross Domestic Product of $\mathrm{Mu}$ nicipalities. [cited 2013 Jul 5]. Available from: http:// www.ibge.gov.br/cidadesat/xtras/perfil.php?codmun $=411370 \& a m p ; a m p ; s e a r c h=$ parana

21. Silva D, Werneck AO, Collings P, Tomeleri CM, Fernandes RA, Ronque E, Venturini D, Barbosa DS, Coelho-E-Silva MJ, Sardinha LB, Cyrino ES. Cardiorespiratory fitness is related to metabolic risk independent of physical activity in boys but not girls from Southern Brazil. Am J Hum Biol 2016; 28(4):534-538.

22. Baecke JAH, Burema J, Frijters JER. A short questionnaire for the measurement of habitual physical-activity in epidemiological-studies. Am J Clin Nutr 1982; 36(5):936-942.

23. Associação Brasileira de Empresas de Pesquisa (ABEP). Dados com base no Levantamento Socioeconômico. São Paulo: ABEP; 2000.

24. Mirwald RL, Baxter-Jones ADG, Bailey DA, Beunen GP. An assessment of maturity from anthropometric measurements. Med Sci Sports Exerc 2002; 34(4):689-694.

25. Dumith SC, Gigante DP, Domingues MR, Kohl HW III. Physical activity change during adolescence: a systematic review and a pooled analysis. Int J Epidemiol 2011; 40(3):685-698.

26. Collings PJ, Wijndaele $\mathrm{K}$, Corder $\mathrm{K}$, Westgate $\mathrm{K}$, Ridgway CL, Sharp SJ, Dunn V, Goodyer I, Ekelund $\mathrm{U}$, Brage S. Magnitude and determinants of change in objectively-measured physical activity, sedentary time and sleep duration from ages 15 to $17.5 \mathrm{y}$ in UK adolescents: the ROOTS study. International Journal of Behavioral Nutrition and Physical Activity 2015; 12:61.

27. Telama R, Yang XL, Viikari J, Valimaki I, Wanne O, Raitakari O. Physical activity from childhood to adulthood - A 21-year tracking study. Am J Prev Med 2005; 28(3):267-273.

28. De Melo CM, Tirapegui J, Lima Ribeiro SM. Human energetic expenditure: Concepts, assessment methods and relationship to obesity. Arq Bras Endocrinol Metabol 2008; 52(3):452-464.
29. Berg C, Rosengren A, Aires N, Lappas G, Torén K, Thelle D, Lissner L. Trends in overweight and obesity from 1985 to 2002 in Goteborg, West Sweden. Int J Obes (Lond) 2005; 29(8):916-924.

30. Ekelund U, Anderssen SA, Froberg K, et al. Independent associations of physical activity and cardiorespiratory fitness with metabolic risk factors in children: the European youth heart study. Diabetologia 2007; 50(9):1832-1840.

31. Eisenmann JC. Aerobic fitness, fatness and the metabolic syndrome in children and adolescents. Acta Paediatr 2007; 96(12):1723-1729.

32. White AJ, Sandler DP, Bolick SC, Xu Z, Taylor JA, DeRoo LA. Recreational and household physical activity at different time points and DNA global methylation. Eur J Cancer 2013; 49(9):2199-2206.

33. Voisin S, Eynon N, Yan X, Bishop DJ. Exercise training and DNA methylation in humans. Acta Physiol (Oxf) 2015; 213(1):39-59.

34. Christofaro DGD, Fernandes RA, Martins C, Ronque ER, Coelho-e-Silva MJ, Silva AM, Sardinha LB, Cyrino ES. Prevalence of physical activity through the practice of sports among adolescents from Portuguese speaking countries. Cien Saude Colet 2015; 20(4):1199-1206.

35. Farias Júnior JC, Florindo AA, Santos MP, Mota J, Barros MV. Perceived environmental characteristics and psychosocial factors associated with physical activity levels in adolescents from Northeast Brazil: structural equation modelling analysis. J Sports Sci 2014; 32(10):963-973

36. Sherar LB, Cumming SP, Eisenmann JC, Baxter-Jones $\mathrm{AD}$, Malina RM. Adolescent biological maturity and physical activity: biology meets behavior. Pediatr Exerc Sci Aug 2010; 22(3):332-349.

37. Cumming SP, Standage M, Gillison F, Malina RM. Sex differences in exercise behavior during adolescence: is biological maturation a confounding factor? J Adolesc Health 2008; 42(5):480-485.

38. Yliharsila H, Kajantie E, Osmond C, Forsen T, Barker DJP, Eriksson JG. Birth size, adult body composition and muscle strength in later life. Int J Obes Suppl 2007; 31(9):1392-1399.

39. Ridgway CL, Ong KK, Tammelin T, Sharp SJ, Ekelund $\mathrm{U}$, Jarvelin MR. Birth size, infant weight gain, and motor development influence adult physical performance. Med Sci Sports Exerc 2009; 41(6):1212-1221.

40. Godfrey KM, Gluckman PD, Hanson MA. Developmental origins of metabolic disease: life course and intergenerational perspectives. Trends Endocrinol Metab 2010; 21(4):199-205.

41. Brown HE, Atkin AJ, Panter J, Wong G, Chinapaw MJ, van Sluijs EM. Family-based interventions to increase physical activity in children: a systematic review, meta-analysis and realist synthesis. Obes Rev 2016; 17(4):345-360.

42. O'Sullivan JJ, Pearce MS, Parker L. Parental recall of birth weight: how accurate is it? Arch Dis Child 2000; 82(3):202-203.

43. Araújo CL, Dutra CL, Hallal PC. Validity of maternal report on birth weight 11 years after delivery: the 1993 Pelotas Birth Cohort Study, Rio Grande do Sul State, Brazil. Cad Saude Publica 2007; 23(10):2421-2427. 
44. Hallal PC, Dumith SC, Bastos JP, Reichert FF, Siqueira FV, Azevedo MR. Evolution of the epidemiological research on physical activity in Brazil: a systematic review. Rev Saude Publica 2007; 41(3):453-460.

45. Reichert FF, Azevedo MR, Breier A, Gerage AM. Physical activity and prevalence of hypertension in a population-based sample of Brazilian adults and elderly. Prev Med 2009; 49(2-3):200-204.

Artigo apresentado em 19/10/2016

Aprovado em 21/06/2017

Versão final apresentada em 23/06/2017 